\title{
Students' perception of science teachers' instructional strategies in Senior Secondary Schools.
}

\author{
Peter Oladeji Ajayi (Ph.D) \\ Department of Science Education, Faculty of Education, \\ Ekiti State University, Ado-Ekiti, Ekiti State, Nigeria. \\ Titilayo Folayemi Otoide \\ Department of Science Education, Faculty of Education, \\ Ekiti State University, Ado-Ekiti, Ekiti State, Nigeria.
}

\begin{abstract}
The study focused on the perception of students on the instructional strategies used by science teachers in senior secondary schools, using descriptive research of the survey type. The participants were 540 out of 5,318 science students in Ekiti State public Senior Secondary Schools who were selected through multi-stage sampling procedure. An instrument tagged "Science Teachers' Instructional Strategies Scale (STISS)" was used to collect data from science students across the three senatorial districts of Ekiti State. The data collected were collated and analyzed using descriptive and inferential statistics involving mean, standard deviation, Analysis of Variance and t-test. The results of the study revealed that teacher-centred and discipline-centred are the most frequently used instructional strategies by science teachers in senior secondary schools. The results further revealed that the students-centred which is the least frequently used instructional strategies by science teachers is the most alluring to science students. It was therefore recommended among others that government should organize appropriate training through workshops; conferences and seminars for science teachers to enhance professional competencies in their jobs which could as well exposed them to various strategies of teaching which are students-centred. This will help to demystify science in its entirety and simplify the perceived abstract nature of science-concepts which will in turn improve students' enrolment and attitude towards science as well as their academic performance in science to enhance national technological growth with the view of "VISION 2030" and "Sustainable Development Goal" (SDG) in mind.
\end{abstract}

Keywords: Science subjects, Instructional Strategies, Perception, Students, Teachers.

\section{INTRODUCTION}

Science is the study of the nature and behaviour of natural things and the knowledge that is obtain about them. Science according to Jegede and Omotayo (2011) is said to include knowledge of facts and principles of knowledge gained by systematic study. The importance of science to the advancement of a nation's technology cannot be overemphasized. Everything in the universe is a product of science hence the world is science. Any student who wished to pursue a career in science and technological fields in tertiary institutions must pass through science class in the senior secondary school, and more importantly, such student must be well groomed. This is where science teachers' roles come to play. The instructional strategies used by science teachers have a lot to do in grooming the students as future renowned scientists. Instructional strategies are the means employed by science teachers for instruction in science which is aimed at assisting the students to acquire the needed skills for critical thinking and the general nature of science. Azizoglu and Cetin (2009) submitted that the purpose of science education is to develop a positive attitude towards science regardless of individual differences. 
One of the ways of developing positive attitudes in students however, is through the use of appropriate instructional strategies. Despite the innovations in science, the rate at which science students do shift to other disciplines such as arts and commercial calls for urgent attention. This problem has been traced to poor science teaching strategies in the secondary schools and tertiary institutions. Several researchers such as Owolabi (2004), Jegede (2007) and Hakielimu (2011) have proved that the performance of students or learning outcome in most cases is a function of the instructional strategies employed by the teacher. The nature of science calls for a unique way of teaching it, hence the need for science teachers to acquire more skills that will aid teaching and learning, one of which is the use of appropriate instructional strategies.

Teachers are the most crucial inputs of any educational system and they influence to a great extent, the quality of educational output (Fadipe, 2003). They are the fulcrum on which the lever of educational system rests (Achimugu, 2005). In agreement to this, the National Policy on Education (2013) stated that no educational system can rise above the quality of its teachers. In short, teachers are the key ingredient in determining the quality of education (Hakielimu, 2011). A teacher who is deficient in good instructional strategy will always produce poor students (Aina \& Olanipekun, 2015). Similarly, a teacher who cannot motivate his or her student to learn either through teacher-student interaction or student-student interaction will produce poor students. Most students in Nigerian schools are not ready to learn, hence, teachers who could impact positively on them through effective teaching strategies are needed. In support of this, Bandele (2008) was of the opinion that there is the need for teachers to be equipped with the modern methods of impacting knowledge to students.

The choice of teaching strategy to be used depends largely on the information or skill that is being taught. This is in agreement with the submission of Jegede (2010) that a method is said to be good only when it is appropriate for the status of learner, situation on ground and the type of content to be disseminated. In support of this, the researcher is of the opinion that a teacher should have good understanding of the individual students in his class to enable him choose the appropriate instructional strategy or strategies that will fit the individual differences among the students.

In science teaching, there are three broad instructional strategies, namely; discipline-centred, teacher- centred and student- centred. Disciplined-centred instruction focuses more on the subject matter than on what the teacher does. The aim is to teach content as prescribed in the syllabus or textbook regardless of whether it meets the needs of students or not. In teachercentred instruction, the teacher is the focus, acting as the main source of knowledge and the focal point. The teacher usually dominate the class as the authoritative expert and the students are either passive (just sit down and listening) or slightly involved. It happened to be one of the fasted ways of covering the syllabus but it does not put into consideration the individual differences among students. A student-centred instruction focused on students. It allows for a dynamic classroom environment, and is most effective for teaching the "process than product". The focus is on learners, their cognitive abilities and interests. The teacher's concern is how to make the learners take an active role in their learning by making them to conduct their own investigations, develop their ideas, and share ideas with others through discussions and collaborative work. Asoodeh, Asoodeh and Zarepour (2012) submitted that students-centred instructional strategies are effective means of helping students to learn, retain and reproduce what they have learnt. This is supported by Jegede and Awodun (2015) that student centred instructional strategies is more potent in changing students' attitude towards physics (a science subject). On the contrary, Emaliana (2017) affirmed that not only student-centred, but 
also, teacher-centred instructional strategies can be used to enhance effective teaching and learning at different levels of education.

Good knowledge and mastery of the various methods of teaching science could assist the teacher to know when to use a particular method or not. It could also assist the teacher to know when to combine two or more methods for effective teaching and learning. Boundless (2016) is of the view that the combination of two or more of these strategies usually make teaching and learning effective.

Science education is the vehicle that conveyed scientific knowledge and skills to the people who are in need of capacities and potentials for developing (Emmanuel, 2013). Hence there is need for the use of appropriate and effective instructional strategies for the teaching and learning of science subjects in senior secondary schools. However, despite its important role in the advancement of the society, it appears that the instructional strategies commonly used by science teachers are not appropriate and effective enough to improving students' enrolment, participation and learning outcomes to enhance national technological growth with the view of "VISION 2020" and "Sustainable Development Goal" (SDG) in mind. In view of this, the research was carried out to investigate students' perception of science teachers' instructional strategies in Seniors Secondary Schools.

\section{Purpose of the Study}

The purpose of the study was to investigate the instructional strategies used by science teachers in senior secondary schools as perceived by the Science students, which of the three core strategies (discipline-centred, teacher- centred and student- centred) of teaching science are frequently used, and to find out which of the strategies is the most alluring to students.

\section{Research Questions}

Two research questions were raised for the study as thus:

1. Which of the three core strategies (discipline-centred, teacher- centred and studentcentred) of teaching science is the most frequently used by science teachers?

2. Which of the instructional strategies is the most alluring to the students?

\section{Research Hypotheses}

Two null hypotheses were postulated to guide the study and were tested at 0.05 level of significance:

1. There is no significant difference in the instructional strategies used by science teachers as perceived by the Science students in senior secondary schools

2. There is no significant difference in the use of instructional strategies by science teachers as perceived by male and female Science students.

\section{Research Design}

\section{METHODOLOGY}

This research employed a descriptive research of the survey type. Descriptive survey research design is a procedure whereby a unit of the population is studied in details so as to generalise the result on the entire population.

\section{Population}

The population for this study comprised all the 5,318 science students in public Senior Secondary Schools in Ekiti State, Nigeria. The figure obtained was as at the time of investigation. (Source: Ekiti State Teaching Service Commission). 


\section{Sample and Sampling Techniques}

A sample of 540 Senior Secondary School science students was drawn from nine local government areas across the three senatorial districts of Ekiti State. The sample was selected using multi-stage sampling procedure. At the first stage, three local government areas were selected from each of the senatorial districts using simple random sampling by balloting. The second stage involved the selection of Senior Secondary School science students across the selected three local government areas in each of the senatorial districts using stratified random sampling technique where Senior Secondary School (SSS) classes 1, 2 and 3 were used as stratification variable. Consequently, 180 students comprising 60 science students from each of SS 1, 2 and 3, were randomly selected from the nine local government areas chosen for this study, making a total of 540 science students across the three senatorial districts.

\section{Research Instrument}

A questionnaire tagged "Science Teachers' Instructional Strategies Scale (STISS)" was the only instrument used for the study. The instrument was developed to measure the frequency of instructional strategies used by science teachers as perceived by students. The instrument consists of sections A and B. Section A consists of the respondents' bio-data and preliminary information for science students while section B consists of a 12 item statements which were used to elicit information on the perceived science teachers' instructional strategies. The responses were scored as follows: Very Often (VO) - 4 points; Often (O) - 3 points; Less Often (LO) - 2 points; Not Often (NO) - 1 point.

\section{Validity and Reliability of the Instrument}

Face and content validity of the instrument were ascertained by experts in the field of Science Education, Test, Measurement and Evaluation. A reliability coefficient of 0.83 was obtained through split half method.

\section{Data Analysis}

Data collected were collated and analysed using descriptive and inferential statistics. The questions raised were answered using descriptive statistics involving mean and standard deviation, while the hypotheses postulated were analysed using inferential statistics involving Analysis of variance(ANOVA) and t-test. Decisions were taken at 0.05 levels of significance.

\section{RESULTS AND DISCUSSIONS}

Research Question 1: Which of the three core strategies (discipline-centred, teacher- centred and student- centred) of teaching science is the most frequently used by science teachers?

Table 1: Mean Rating of Students' Perception of Instructional Strategy Frequently used by Science Teachers

\begin{tabular}{lcccc}
\hline Instructional Strategy & $\mathbf{N}$ & Mean & SD & Rank \\
\hline Teacher - Centred & 540 & 12.56 & 1.49 & $1^{\text {st }}$ \\
Discipline - Centred & 540 & 11.46 & 1.31 & $2^{\text {nd }}$ \\
Student - Centred & 540 & 8.86 & 1.55 & $3^{\text {rd }}$ \\
\hline Mean Average & $\mathbf{5 4 0}$ & $\mathbf{1 0 . 9 6}$ & $\mathbf{1 . 4 5}$ & \\
\hline
\end{tabular}

The information contained in table 1 revealed that mean rating of students' perception of instructional strategy frequently used by science teachers ranges from $8.86-12.56$. The most frequently used instructional strategy by science teachers as perceived by students was teacher-centred, followed by disciplined - centred while the least perceived frequently used was student-centred. Also, the standard deviation which ranges from $1.31-1.55$ indicates that the respondents were very close in their ratings. Using the mean average, result shows that 
teacher-centred and discipline - centred which had mean scores above the mean average of 10.96 are the most frequently used instructional strategies by science teachers.

Research question 2: Which of the instructional strategies is the most alluring to the students?

Table 2: Mean Rating of Instructional Strategy Perceived Most Alluring by Science Students

\begin{tabular}{lcccc}
\hline Instructional Strategy & $\mathbf{N}$ & Mean & SD & Rank \\
\hline Student - Centred & 540 & 3.23 & 0.95 & $1^{\text {st }}$ \\
Teacher - Centred & 540 & 2.59 & 1.01 & $2^{\text {nd }}$ \\
Discipline - Centred & 540 & 2.23 & 0.92 & $3^{\text {rd }}$ \\
\hline Mean Average & $\mathbf{5 4 0}$ & $\mathbf{2 . 6 8}$ & $\mathbf{0 . 9 6}$ & \\
\hline
\end{tabular}

Table 2 shows that mean rating of instructional strategy perceived most alluring by students ranges from $2.23-3.23$. The most alluring instructional strategy to students was studentcentred, followed by teacher - centred, while the least alluring was disciplined-centred. The standard deviation which ranges from $0.92-1.01$ indicates that the respondents were very close in their ratings. Using the mean average, result shows that only the student-centred had the mean value above the mean average of 2.68 which implies that students- centred instructional strategies are the most alluring instructional strategies to students as perceived by science students.

Hypothesis 1: There is no significant difference among the instructional strategies used by science teachers in senior secondary schools

Table 3: Analysis of Variance (ANOVA) of difference among the instructional strategies used by science teachers in senior secondary schools

\begin{tabular}{lccccc}
\hline Source & SS & Df & MS & F & Sig. \\
\hline Between Groups & 3900.009 & 2 & 1950.004 & 920.505 & .000 \\
Within Groups & 3425.463 & 1617 & 2.118 & & \\
\hline Total & 7325.472 & 1619 & & & \\
\hline
\end{tabular}

$* \mathrm{P}<0.05$

Table 3 shows that F-calculated was 920.505 while the corresponding p-value was $0.000<0.05$ level of significance. Since p-value of 0.000 was less than 0.05 level of significance, the null hypothesis was rejected. Therefore, there is significant difference among the instructional strategies used by science teachers in senior secondary schools. In order to identify the point of differences, Scheffe Post Hoc Multiple Comparison was carried out. The result is presented in Table 4. 
Table 4: Scheffe Post Hoc Multiple Comparisons of difference among the instructional strategies used by science teachers in senior secondary schools

\begin{tabular}{llccc}
\hline $\begin{array}{c}\text { (I) } \\
\text { Grouping }\end{array}$ & \multicolumn{1}{c}{ (J) Grouping } & $\begin{array}{c}\text { Mean Difference } \\
\text { (I-J) }\end{array}$ & Std. Error & Sig. \\
\hline Discipline - Centred & Teacher - Centred & $-1.10556^{*}$ & .08858 & .000 \\
& Student - Centred & $2.59630^{*}$ & .08858 & .000 \\
\hline Teacher - Centred & Discipline - Centred & $1.10556^{*}$ & .08858 & .000 \\
& Student - Centred & $3.70185^{*}$ & .08858 & .000 \\
\hline Student - Centred & Discipline - Centred & $-2.59630^{*}$ & .08858 & .000 \\
& Teacher - Centred & $-3.70185^{*}$ & .08858 & .000 \\
\hline
\end{tabular}

*The mean difference is significant at the 0.05 level.

Table 4 shows that teacher-centred instructional strategy is more used by science teachers over discipline-centred and student-centred as discipline - centred was more used than student-centred.

Hypothesis 2: There is no significant difference in the perception of instructional strategies used by science teachers by male and female students

Table 5: t-test analysis of difference in the perception of male and female students on instructional strategies used by science teachers

\begin{tabular}{|c|c|c|c|c|c|c|c|}
\hline Instructional Strategy & Gender & $\mathbf{N}$ & Mean & S.D & df & $\mathbf{T}$ & Sig. \\
\hline \multirow[t]{2}{*}{ Discipline - Centred } & Male & 266 & $\overline{11.15}$ & 1.38 & \multirow{6}{*}{538} & -5.489 & .000 \\
\hline & Female & 274 & 11.75 & 1.17 & & & \\
\hline \multirow[t]{2}{*}{ Teacher - Centred } & Male & 266 & 12.35 & 1.33 & & -3.243 & .001 \\
\hline & Female & 274 & 12.76 & 1.61 & & & \\
\hline \multirow[t]{2}{*}{ Student - Centred } & Male & 266 & 8.76 & 1.38 & & -1.394 & .164 \\
\hline & Female & 274 & 8.95 & 1.68 & & & \\
\hline
\end{tabular}

Data contain in table 5 shows that female perceived discipline-centred and teacher-centred instructional strategies more frequently used by science teachers than their male counterparts $(\mathrm{t}=-5.489, \mathrm{df}=538, \mathrm{p}<0.05$ and $\mathrm{t}=-3.243, \mathrm{df}=538 . \mathrm{p}<0.05)$ respectively. The mean and standard deviation of discipline-centred and teacher-centred for male and female responses were 11.15(1.38); 11.75(1.17) and 12.35(1.33); 12.76(1.61) respectively. For student-centred, the mean and standard deviation shows 8.76(1.38) and 8.95(1.68) for male and female respondents respectively, while the t-calculated value was -1.394 and the corresponding $\mathrm{p}$ value was 0.164 at 0.05 level of significance. Therefore, the null hypothesis was rejected for discipline-centred and teacher-centred but accepted for student-centred. Hence, there is significant difference in the perception of male and female students on instructional strategies used by science teachers except for student-centred instructional strategies.

\section{DISCUSSION}

The findings of the study indicated that teacher-centred and discipline-centred which had mean scores above the mean average are the most frequently used instructional strategies by science teachers.

It was also discovered from the findings that only student-centred had the mean value above the mean average which implies that the most alluring instructional strategies are studentscentred. This is in line with the submissions of Asoodeh, Asoodey and Zarepour (2012) that students-centred instructional strategies are effective means of helping students to learn, 
retain and reproduce what they have learnt. This might not be far from the truth as the majority of the students confirmed in their responses that they enjoyed participating in teaching and learning activities than to just sit down and listen during teaching. In agreement, Jegede and Awodun (2015) confirmed that outdoor teaching approach which is a good example of student-centred instructional strategies is more potent in changing students' attitude towards physics (a science subject) than the conventional teaching method.

Contrariwise, Harmer (2011) opined that no single teaching method can possibly 'perform the magic', which means that various teaching methods should be used by teachers to meet all of students' individual needs. In the same vein, Boundless (2016) strengthens that the combination of two or more instructional strategies will make teaching and learning effective in science.

Emaliana (2017) also affirmed that not only student-centred, but also, teacher-centred instructional strategies can be used to enhance effective teaching and learning at different levels of education.

Another finding affirmed that there is significant difference among the instructional strategies used by science teachers with teacher-centred instructional strategies more frequently used by science teachers over discipline centred and student-centred while discipline-centred was more used than student-centred. The study also found that there is significant difference in the perception of male and female students on instructional strategies used by science teachers except for student-centred instructional strategies. Researchers such as Wijesundera and Ramakrisma in Oluwatelure (2015) affirmed that the issue of gender difference in achievement in school science among learners is far from being resolved. If the issue of gender is unresolved therefore, students' perception of science teachers' instructional strategies may and may not necessarily have anything to do with their genders. .

\section{CONCLUSION}

Based on the findings of this study, it can be concluded that teacher-centred and disciplinecentred are the most frequently used instructional strategies by science teachers in senior secondary schools, which implies that students-centred which is the most alluring instructional strategies as perceived by senior secondary schools science students is the least frequently used by science teachers.

It can also be concluded that the perception of students on science teachers' instructional strategies varied with students' gender except for students-centred instructional strategies which was found not to vary with students' gender.

\section{RECOMMENDATIONS}

Based on the findings of this study, the following recommendations were made:

1. Since disciplined-centred and teacher-centred instructional strategies frequently used in senior secondary schools had been discovered in this study to be less alluring to science students than students-centred instructional strategies, science teachers should be encouraged to focus more on students-centred instructional strategies in order to demystify science in its entirety and simplify the perceived abstract nature of scienceconcepts to improve students' attitude towards science and their academic performance in science.

2. Government should organize appropriate training through workshops, conferences and seminars for science teachers to enhance professional competencies in their jobs which could as well exposed them to various strategies of teaching which are students- 
centred. This will enable them to inculcate in their students, the right attitude towards science which could further improve students' enrolment, participation and learning outcomes to enhance national technological growth with the view of "VISION 2020" and "Sustainable Development Goal" (SDG) in mind.

\section{References}

Achimugu, L. (2005). The agonies of Nigeria teachers. Ibadan: Heinemann Education Publishers Limited.

Aina, J.K \& Olanipekun, S.S. (2015). A Review of Teachers' Qualifications and Its Implication on Students' Academic Achievement in Nigerian Schools. International Journal of Educational Research and information Science, $2(2), 10-15$.

Asoodeh, M.H, Asoodeh, M.B, \& Zarepour, M. (2012). The Impact of Student-Centred Learning on Academic Achievement and Social Skills. Procedia-Social and Behavioural Sciences, 560-564. Available online at www.sciencedirect.com

Azizoglu, N. \& Cetin, G. (2009). The Effect of Learning Style on Middle Schools Students' Motivation and Attitudes Towards Science, and the Relationships Among these Variables. Kastamonu Education Journal, (1), 171-182.

Bandele, S.O. (2008). Towards Effective, Efficient and Qualitative Service Delivery in Secondary Schools. Ekiti State Teaching Service Commission Journal, 1-7.

Boundless. (2016, August)."Accuracy,Precision,and Error." Boundless Boundless. Retrieved August 21st, 2017, from http://www.boundless.com/chemistry/textbooks/boundless-chemistry-textbook/introduction-tochemistry-1/measurement-uncetainty-30/accuracy-precision-and-error-1990-3706/

Emaliana, I. (2017). Teacher-Centred or Student-Centred Learning Approach to Improve Learning? Jurnal Sosial Humaniora, 10, 1979-5521

Emmanuel, B.(2013). The Place of Nigeria Certificate in Education Chemistry Teachers in UBE Basic Science Programme. Science Teachers Association of Nigeria (STAN), 54th Annual conference proceedings, 171-181

Fadipe, J.O. (2003). Quality control in education: The teacher factor. In T.E. Ajayi and J. Fadipe(Eds). Skills Improvement Programme for Effective Performance of Teachers in Nigerian Schools(pp128-143). Ondo: A publication of National Institute for Educational Planning and Administration(NIEPA).

Federal Republic of Nigeria (2013). National Policy on Education( $6^{\text {th }}$ ed).Yaba, Lagos:National Education Research Development Council Press.

Hakielimu. (2011). Are our Teachers Qualified and Motivated to Teach?A research report on teachers' qualifications, motivation and commitment to teach and their implications on quality education.

Harmer, Jeremy (2011). The Practice of English Language Teaching. Longman: New York

Jegede, S.A. (2007). The Relative Effectiveness of Discursion and Excursion Methods on Senior Secondary Schools students' achievement in Chemistry. Educational Focus (EDFOC), 1(1), 96.

Jegede, S.A. (2010). Curriculum Implementation: From Curriculum to Lesson Plan: An Overview. In S.A. Jegede \& A.A. Popoola (Eds). The Dynamics of Instruction(pp18-30). Lagos: Premier Publishers.

Jegede, S.A. \& Omotayo, K.A.(2011). Science Education and Teaching Methods. Ado-Ekiti. Green line Publisher. Jegede, S.A. \& Awodun, A.O. (2015). Effects of Outdoor Activities on Students' Attitudes towards Physics in Secondary Schools. Internationa Journal for Innovation Education and Reasearch, 3(5).

Oluwatelure, T.A. (2015). Gender Difference in Achievement and attitude of Public Secondary School students towards science. Journal of Education and Practice, 6(2)

Owolabi, O.T. (2004). A diagnosis of Students' difficulty in Physics Education Perspective, 7, 15-20 